\title{
In situ occurrence of Muong Nong-type Australasian tektite fragments from the Quaternary deposits near Huai Om, northeastern Thailand
}

\author{
Toshihiro Tada ${ }^{1 *}$ (D) Ryuji Tada ${ }^{1,2,3}$, Praphas Chansom ${ }^{4}$, Wickanet Songtham ${ }^{4}$, Paul A. Carling ${ }^{5}$ and Eiichi Tajika ${ }^{1}$
}

\begin{abstract}
There are several reports of Australasian tektites found within a stratum called "laterite" layer widely distributed in Indochina. However, it has been debated whether these tektites are in situ or reworked. This uncertainty is because a detailed description of their field occurrence is lacking. Here, we describe the detailed occurrence of a cluster of tektite fragments recovered from the "laterite" layer near Huai Om, northeastern Thailand, and demonstrate the evidence of in situ occurrence of the tektites. At least 331 tektite fragments with a total weight of $713 \mathrm{~g}$ were found from a $40 \times 30 \mathrm{~cm}$ area with $10 \mathrm{~cm}$ thickness in the uppermost part of the "laterite" layer. The very angular shapes and very poorly sorted nature of the fragments, restoration of larger tektite fragments into one ellipsoidal Muong Nong-type (MN) tektite mass, and the similar chemical composition of the fragments suggest that these MN tektite fragments represent a tektite mass that fragmented in situ. The fact that the fragments were found within the "laterite" layer is inconsistent with a previous interpretation that the upper surface of the "laterite" layer is a paleoerosional surface, on which the tektites are reworked. The size distribution of the fragments is bi-fractal following two power laws in the range from 10 to $26 \mathrm{~mm}$ and from 26 to $37 \mathrm{~mm}$, respectively, with fractal dimensions (Ds) of 2.2 and 7.5. The Ds for the coarse fraction of the tektite fragments is larger than the Ds for rock fragments generated by rockfalls and rock avalanches and similar to the Ds for the coarser fraction fragments generated by high-speed impact experiments, suggesting that the tektite fragments were formed through intense fragmentation by a relatively high energetic process. The occurrence of the fragments forming a cluster indicates that the fragments were not moved apart significantly after fragmentation and burial. Based on these results, we concluded that the mass of a tektite was fragmented at the time of the landing on the ground after traveling a ballistic trajectory and has not been disturbed further.
\end{abstract}

Keywords: Australasian tektite, Impact ejecta, Southeast Asia

\section{Introduction}

Tektites are objects composed entirely of glass formed by meteorite impacts (Koeberl 1994). Tektites are found from at least four broad areas of the Earth's surface, called strewn fields (e.g., Koeberl 1994; Glass and

\footnotetext{
* Correspondence: ttada@eps.s.u-tokyo.ac.jp

'Department of Earth and Planetary Science, The University of Tokyo, 7-3-1

Hongo, Bunkyo-Ku, Tokyo 113-0033, Japan

Full list of author information is available at the end of the article
}

Simonson 2012). The Australasian tektites were formed ca. 0.8 Ma and occur as the largest and youngest strewn field extending from southwestern China, through Indochina, Australia to Antarctica (Folco et al. 2016). Despite the largest size and youngest age of the strewn field, the source crater has never been identified. Nevertheless, it is expected that the record of the impact and consequent environmental perturbations are well preserved because the impact event which made Australasian tektites (here 
we term the Australasian Tektite Event; AATE) is the youngest among the large impact events on the Earth. Thus, the AATE has broader significance to the study of the meteorite impact phenomena on Earth.

Based on their morphology, Australasian tektites have been classified into three groups (e.g., Koeberl 1994): (1) splash-form tektites, (2) ablated form tektites, and (3) Muong Nong-type (MN) tektites (also called layered tektites). Among these, MN tektites have blocky shapes and internal layered texture. Their sizes are typically $>10$ $\mathrm{cm}$, and the largest $\mathrm{MN}$ tektite so far recovered weighs $24.1 \mathrm{~kg}$ (Koeberl 1992). MN tektites primarily are distributed across southern Laos, northeastern Thailand, Vietnam, Cambodia, and Hainan island in China (Fig. 1) (Schnetzler 1992; Wasson et al. 1995; Schnetzler and McHone 1996; Fiske et al. 1999).

Although there are a large number of studies on the geochemistry and microstructure of Australasian tektites, many of them were conducted on samples of unknown or uncertain provenance (e.g., Fudali et al. 1987;

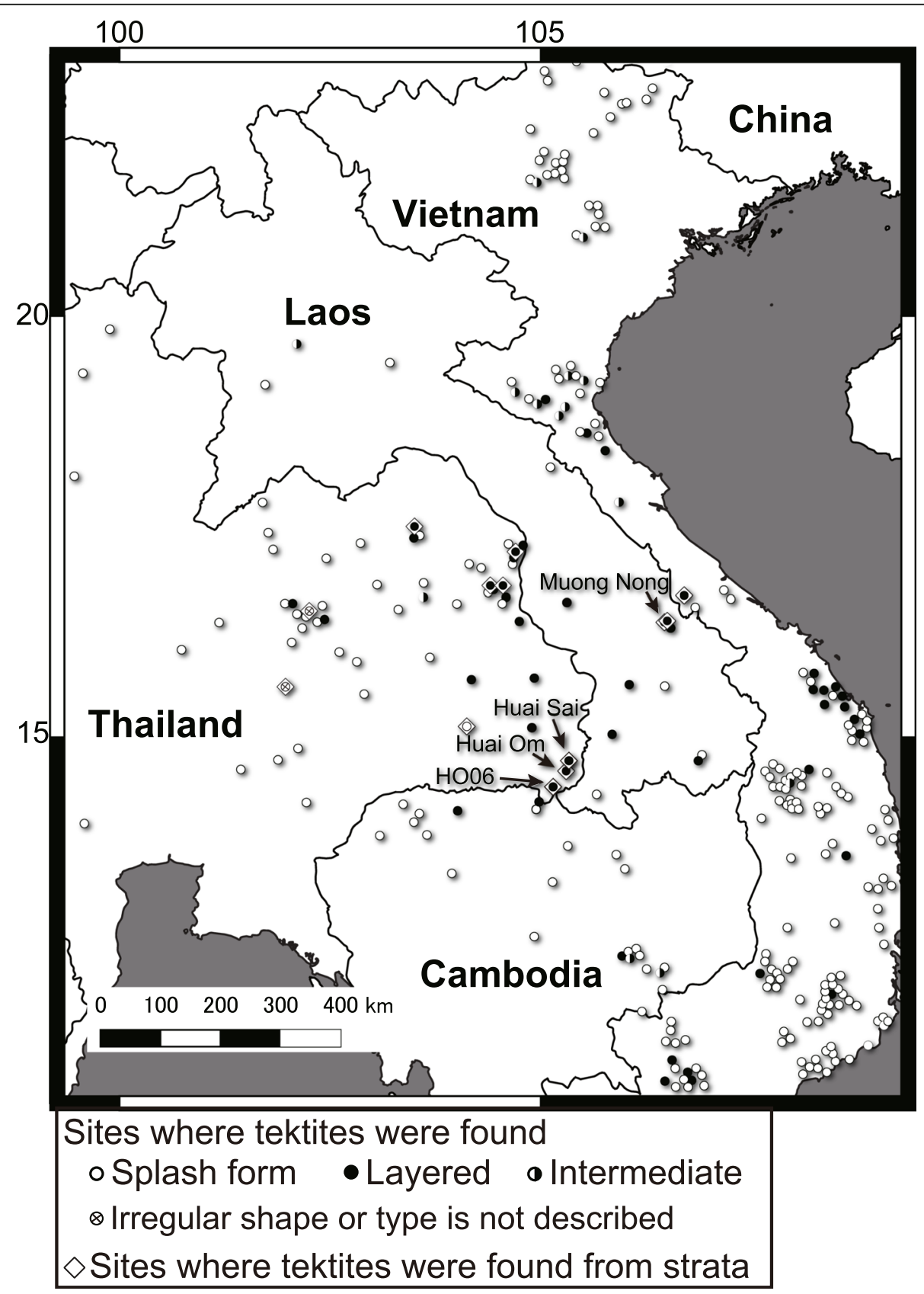

Fig 1 Map of Indochina showing sites where Australasian tektites have been found. Sites where the tektites were found from strata are also shown (after Schnetzler 1992 and references listed in Table 1). The names of locations mentioned in the text are also shown 
Wasson 1991; Schnetzler and McHone 1996; Herzog et al. 2008). There are several reports of tektites found in the Quaternary deposits of Indochina (Fig. 1), of which some occurrences are listed in Table 1 (Barnes and Pitakpaivan 1962; Tamura 1992; Wasson et al. 1995; Fiske et al. 1996, 1999; Schnetzler and McHone 1996; Songtham et al. 2011, 2012). In these studies, tektites were found in a loose gravel (granule to pebble-bearing sand) layer with abundant reddish-black spherical- to irregular-shaped ferruginous nodules, called a "laterite" layer, but the details of the occurrence of the tektites were not described.

Several authors have considered that the tektites recovered from the "laterite" layer were directly deposited in the strata from which they were recovered and hence were found in situ (Wongsomsak 1986; Tamura 1992; Songtham et al. 2011, 2012; Nuchanong et al. 2014). However, the possibility that the tektites have been reworked has been claimed based on reasoning advanced below (Fiske et al. 1996; Koeberl and Glass 2000; Keates 2000; Langbroek 2015).

Fiske et al. (1996) conducted field surveys at two sites: Huai Sai and Huai Om in northeastern Thailand. At Huai Om, they found two MN tektite fragments from the top of the "laterite" layer exposed along a dam spillway. At Huai Sai, they excavated a $2 \times 3 \mathrm{~m}$ area and found 1139 fragments of a MN tektite forming a cluster at the top boundary of the "laterite" layer. Based on the size distribution of the tektite fragments that follows a power law, similar chemical composition of each fragment, and the fact that many fragments form a cluster, Fiske et al. (1996) concluded that the tektite fragments originated from one large tektite mass that underwent fragmentation.

Fiske et al. (1996) interpreted the top of the "laterite" layer as a paleo-erosional surface based on the hardcemented appearance (of the upper surface of the "laterite" layer) that looks like an erosional pavement and interpreted the MN tektite fragments found at the upper boundary of the "laterite" layer to have been reworked on the paleo-erosional surface. However, the interpretation that the upper boundary of the "laterite" layer represents a paleo-erosional surface is based only on their visual observation of the upper surface of the "laterite" layer in the field. Despite concluding that the tektites are reworked, Fiske et al. (1996) noted that there was little evidence that the tektite fragments have undergone significant lateral transport and remained clustered. Thus, the interpretation of Fiske et al. (1996) that tektites found at the top of the "laterite" layer are of reworked origin does not seem to be well supported by their own observations. Nonetheless, this point has long been overlooked and their conclusion that most tektites have been reworked has been widely accepted. Australasian tektites in Australia generally are found in deposits that have been dated as younger in age than the impact event, and thus, these tektites are considered to be reworked (e.g., Fudali 1993). By analogy with the observation in Australia, Koeberl and Glass (2000) and Keates (2000) argued that tektites found in Indochina might also have been reworked, although no field evidence from SE Asia was advanced.

In this study, we report a detailed occurrence of tektite fragments found within the "laterite" layer at a section designated HOO6 located about $15 \mathrm{~km}$ southwest of Huai Om in northeastern Thailand in order to test whether the MN tektite fragments of similar occurrence are of primary depositional origin or reworked. We conducted a field survey at the HO06 section and made a detailed description of the field occurrence of the MN tektite fragments. We also measured the major element compositions of nine MN tektite fragments by electron probe microanalysis (EPMA) to confirm that these glass fragments are Australasian $\mathrm{MN}$ tektites and to demonstrate that these fragments have chemical composition similar to each other. We restored a part of an original tektite mass using large tektite fragments recovered from a block sample to demonstrate that tektite fragments forming a cluster originally formed a large MN tektite mass.

\section{Study site and lithostratigraphy}

The HO06 section (14'34' 45.2" $\left.\mathrm{N} 105^{\circ} 16^{\prime} 30.0^{\prime \prime} \mathrm{E}\right)$ is located about $15 \mathrm{~km}$ southwest of Huai Om, Ubon Ratchatani Province, northeastern Thailand (Fig. 1). As noted above, Fiske et al. (1996) reported MN tektites from the top of the "laterite" layer at Huai Om. The HO06 section is exposed along the spillway of reservoirs named Huai Phueng and Phlan Suea Ton Lang (Fig. 2). The weathered Cretaceous sedimentary basement and overlying Quaternary deposits are exposed continuously laterally for at least $200 \mathrm{~m}$ along both sides of the spillway. A cluster of Australasian MN tektite fragments was found in the section at the north bank. We did not find any evidence of tectonic disturbance of the basement and the overlying Quaternary deposits.

The basement rock at the HO06 section is whitish gray (weathered) to purplish-gray (less weathered) very fine quartzo-feldspathic sandstone of the Cretaceous Khok Kruat Formation, the uppermost part of the Khorat Group (Nuchanong et al. 2014). The exposed thickness of the basement sandstone is approximately 2 $\mathrm{m}$. The basement sandstone dips approximately $10^{\circ}$ to the west and is exposed continuously along the spillway (Fig. 3a, b).

The Quaternary deposits overlie the Cretaceous basement unconformably and can be divided into three lithostratigraphic units (Units 1 to 3 in ascending order; Fig. 3) that are similar to those reported at Huai Om 
Table 1 Sites in Indochina where Australasian tektites were reported in strata

\begin{tabular}{|c|c|c|c|c|}
\hline Locality & Country & Latitude & Longitude & $\begin{array}{l}\text { Tekti } \\
\text { type }\end{array}$ \\
\hline Phang Daeng ${ }^{a}$ & Thailand & $\mathrm{N} 16^{\circ} 48^{\prime}$ & E $104^{\circ} 24^{\prime}$ & $\mathrm{MN}$ \\
\hline Nong Sapong ${ }^{a}$ & Thailand & $N 17^{\circ} 12^{\prime}$ & E $104^{\circ} 42^{\prime}$ & MN \\
\hline $\begin{array}{l}81 \text { km west of Nakhon } \\
\text { Sakhon }^{a}\end{array}$ & Thailand & $\mathrm{N} 17^{\circ} 30^{\prime}$ & E $103^{\circ} 30^{\prime}$ & MN \\
\hline Huai Sai & Thailand & $N 14^{\circ} 53^{\prime}$ & E $105^{\circ} 25^{\prime}$ & MN \\
\hline
\end{tabular}

\section{Occurrence}

At least $10 \mathrm{~kg}$ of $\mathrm{MN}$ tektite fragments were found in the "laterite" layer, $\sim 0.3 \mathrm{~m}$ below the ground surface. Tektite fragments were concentrated in a small area

MN tektite fragments were found in the "laterite" layer, $0.7 \mathrm{~m}$ below the ground surface. Tektite fragments were concentrated in a small area

MN tektite fragments were found in the

"laterite" layer, $0.7 \mathrm{~m}$ below the ground surface

Huai Om

Thailand $\mathrm{N} 14^{\circ} 35^{\prime} \quad$ E $105^{\circ} 17^{\prime} \quad \mathrm{MN}$

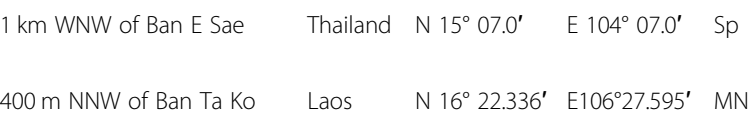

$500 \mathrm{~m} \mathrm{~N}$ of the entrance of Muong Nong

$7 \mathrm{~km} \mathrm{~N}$ of Khe Sahn

$\sim 1 \mathrm{~km} \mathrm{~S}$ of Xeno

$\sim 9 \mathrm{~km} \mathrm{~S}$ of Xeno

$\sim 11 \mathrm{~km}$ of Xeno

Ban Fang

Khon Kaen University

Ban Non Chai

Ban Samran

Ban Khan Kaem Khun

Noen Sa-nga Vietnam N 16 40.71' E $106^{\circ} 42.33^{\prime} \quad M N$

Laos N $16^{\circ} 22.800^{\prime}$ E $106^{\circ} 30.00^{\prime}$ MN

Laos

N $16^{\circ} 39.6^{\prime}$

E $105^{\circ} 00.5^{\prime \prime}$

MN

Laos

N $16^{\circ} 35.2^{\prime}$

E $105^{\circ} 02.3^{\prime} \quad \mathrm{MN}$

Laos

N $16^{\circ} 34.2^{\prime}$

E $105^{\circ} 01.9^{\prime} \quad M N$

Thailand N 16 $27.83^{\prime} \quad$ E $102^{\circ} 37.83^{\prime}$ Not described

Thailand $N 16^{\circ} 28.83^{\prime} \quad$ E $102^{\circ} 49.91^{\prime}$ Not described

Thailand $N 16^{\circ} 22.83^{\prime} \quad$ E $102^{\circ} 51.45^{\prime}$ Not described

Thailand N $16^{\circ} 32.73^{\prime} \quad$ E $102^{\circ} 49.85^{\prime}$ Not described

Thailand N 16 40.50' E $102^{\circ} 48.33^{\prime}$ Not described

Thailand $N 15^{\circ} 36.50^{\prime} \quad E 101^{\circ} 58.00^{\prime}$ Irregular shape
A cluster of $1139 \mathrm{MN}$ tektite fragments with a total mass of $6 \mathrm{~kg}$ was partly exposed at the surface. The largest piece weighed $701.7 \mathrm{~g}$ The fragments were concentrated in $2 \times 3 \mathrm{~m}$ area and $30 \mathrm{~cm}$ in depth. These fragments were in the uppermost light gray sandy soil layer and in the upper $10 \mathrm{~cm}$ of the quartz pebble-bearing "laterite" layer. Most of the fragments were found at the boundary of these two layers

Two MN tektite fragments with a total weight of $2 \mathrm{~g}$ were found from the top of the "laterite" layer. $14 \mathrm{MN}$ tektite fragments with a total weight of $43.5 \mathrm{~g}$ were in float but clearly derived from the immediate strata above

Two splash-form tektites were from the very top of the "laterite" layer

MN tektite fragments were found in the upper $20 \mathrm{~cm}$ of the pebbly "laterite" layer, $\sim 1 \mathrm{~m}$ below the surface. $450 \mathrm{~g}$ of tektite fragments was found in total from a $12 \mathrm{~m}^{2}$ area

Two small MN tektite fragments were found at the top of the pebbly "laterite" layer. Ten fragments of MN tektite with a total mass of $250 \mathrm{~g}$ were found on the surface of a quarry

$86 \mathrm{MN}$ tektite fragments with a total mass of $500 \mathrm{~g}$ were concentrated in the upper $10 \mathrm{~cm}$ of the pebbly quartzite clast layer

Two MN tektite fragments with a total weight of $3.9 \mathrm{~g}$ were found from a reddish "laterite" layer containing scattered quartz pebbles

Four MN tektite fragments with a total weight of $4.8 \mathrm{~g}$ were found from a reddish "laterite" layer containing scattered quartz pebbles

A MN tektite fragment with weight of $3.0 \mathrm{~g}$ was found from a reddish "laterite" layer containing scattered quartz pebbles

One tektite is from the upper part of the "laterite" layer, Tamura 1992 $1.2 \mathrm{~m}$ below the ground surface

One tektite is from the upper part $1.2 \mathrm{~m}$ below the ground surface

One tektite is from the "laterite" layer, partly exposed in the Tamura 1992 ground surface

One tektite is from the "laterite" layer, partly exposed in the Tamura 1992 ground surface

One tektite is from the "laterite" layer, partly exposed in the Tamura 1992 ground surface

A small piece of an irregular-shaped tektite with a weight of $8.75 \mathrm{~g}$ is found at the top of the "laterite" layer

Fiske et al. 1996

Wasson et al. 1995

Fiske et al. 1999

Fiske et al. 1999

Fiske et al. 1999

Schnetzler and McHone 1996

Schnetzler and McHone 1996

Schnetzler and McHone 1996

Tamura 1992

Barnes and

Pitakpaivan 1962

Barnes and Pitakpaivan 1962

Barnes and Pitakpaivan 1962 . 


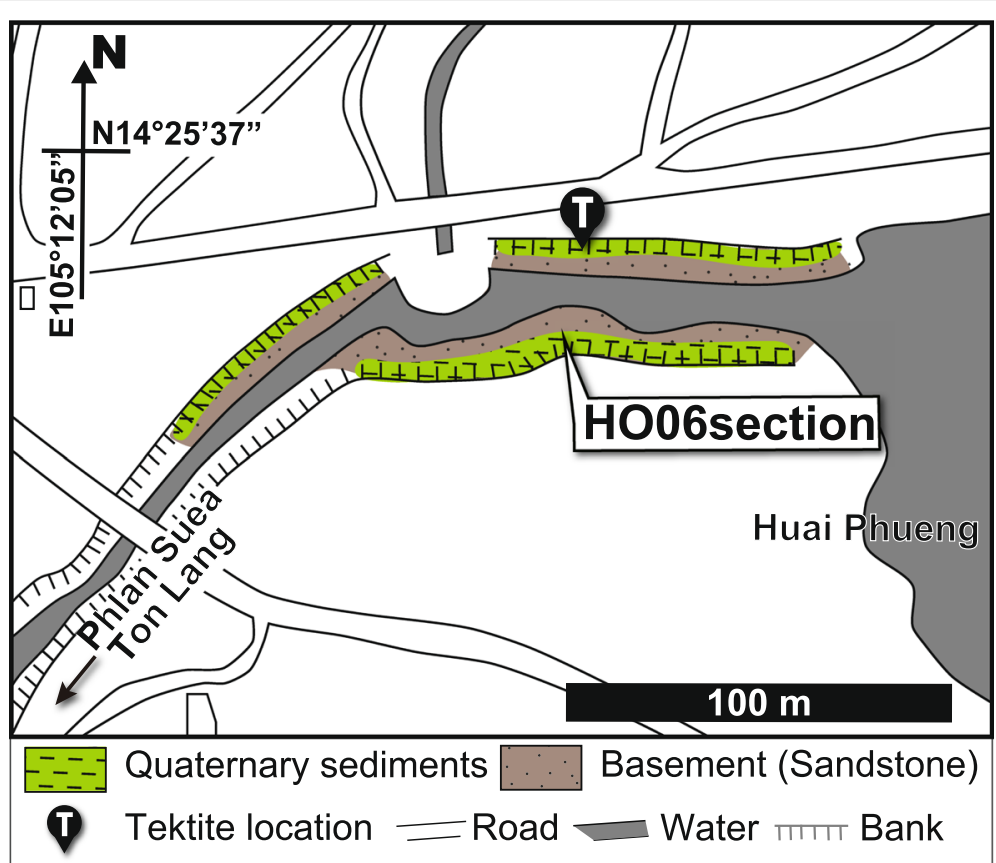

Fig. 2 Locality map of the HOO6 section. The location where we found the cluster of the MN tektite fragments is also shown

section where lithological description was reported (Tada et al. 2019). Unit 1 is a whitish-gray silty very fine sand layer. The thickness of this unit is $70 \mathrm{~cm}$. The basal contact is sharp, largely horizontal, slightly undulating, and forms an angular unconformity (Fig. 3). Unit 2 is a reddish-brown, poorly sorted, granule- to pebble-bearing medium to coarse sand layer. The thickness of this unit is $55 \mathrm{~cm}$. The basal contact is sharp and generally planar. The gravel clasts are $0.2-3 \mathrm{~cm}$ in diameter and are composed mainly of white quartzite pebbles and their fragments (Fig. 3e). This unit is partly cemented by reddishbrown iron oxides to form reddish black pebble size spherical- to irregular-shaped nodules, which are coalescent to each other in some cases (Fig. S1). This observation is consistent with the descriptions of the "laterite" layer (e.g., Songtham et al. 2011, 2012). Unit 3 is composed of whitish- to brownish-gray massive fine sand of $2 \mathrm{~m}$ thickness (Fig. 3d). It overlies Unit 2 with a sharp, planar conformable contact with no evidence of erosion. This unit is capped by ca. $20 \mathrm{~cm}$ thick modern soil with a gradational contact.

The MN tektite fragment cluster was found in the upper part of Unit 2 (ca. $10 \mathrm{~cm}$ below the upper unit boundary) (Fig. 2, 4). The detailed occurrence of the MN tektite fragments is described in the "Results and discussion" section.

\section{Methods}

A block sample of $25 \times 15 \mathrm{~cm}$ area with $10 \mathrm{~cm}$ thickness was taken for three-dimensional (3D) computed tomography $(\mathrm{CT})$ scanning from the area where the $\mathrm{MN}$ tektite fragment cluster was found, using a handheld electric cutter. The block sample was dismantled in the laboratory after the CT scanning, and MN tektite fragments larger than $5 \mathrm{~mm}$ diameter were recovered. After taking the block sample, we further recovered MN tektite fragments by gradually expanding the excavated area until no large ( $>1 \mathrm{~cm}$ diameter) tektite fragments were found. In total, a ca. $40 \times 30 \mathrm{~cm}$ area was excavated. There is a possibility that we overlooked small $(<1 \mathrm{~cm}$ diameter) tektite fragments spread further away.

The major element compositions of nine selected tektite fragments were determined by EPMA on thin sections. EPMA was conducted using a JEOL JXA-8900 L electron probe microanalyzer at the Department of Earth and Planetary Science, the University of Tokyo. The analysis was performed using $15-\mathrm{kV}$ accelerating voltage and 7.5-nA beam current, with a defocused electron beam of $5 \mu \mathrm{m}$. Counting times were $10 \mathrm{~s}$ on peak and $5 \mathrm{~s}$ on the background. Analyzed elements were $\mathrm{Si}, \mathrm{Al}, \mathrm{Fe}$, $\mathrm{K}, \mathrm{Mg}, \mathrm{Ca}, \mathrm{Na}$, $\mathrm{Ti}$, and $\mathrm{Mn}$. Sodium and potassium were analyzed before other elements to reduce possible volatilization effects followed by the method of Glass et al. (2020). The precision of the EPMA was evaluated by the analysis of the composition-known magnetite. Based on the analysis of the magnetite that was repeated ten times, the analytical precision was better than $0.5 \%$ in concentration for all the elements.

Ten to twenty points were measured on each thin section. Because the total percentage of measured elements 

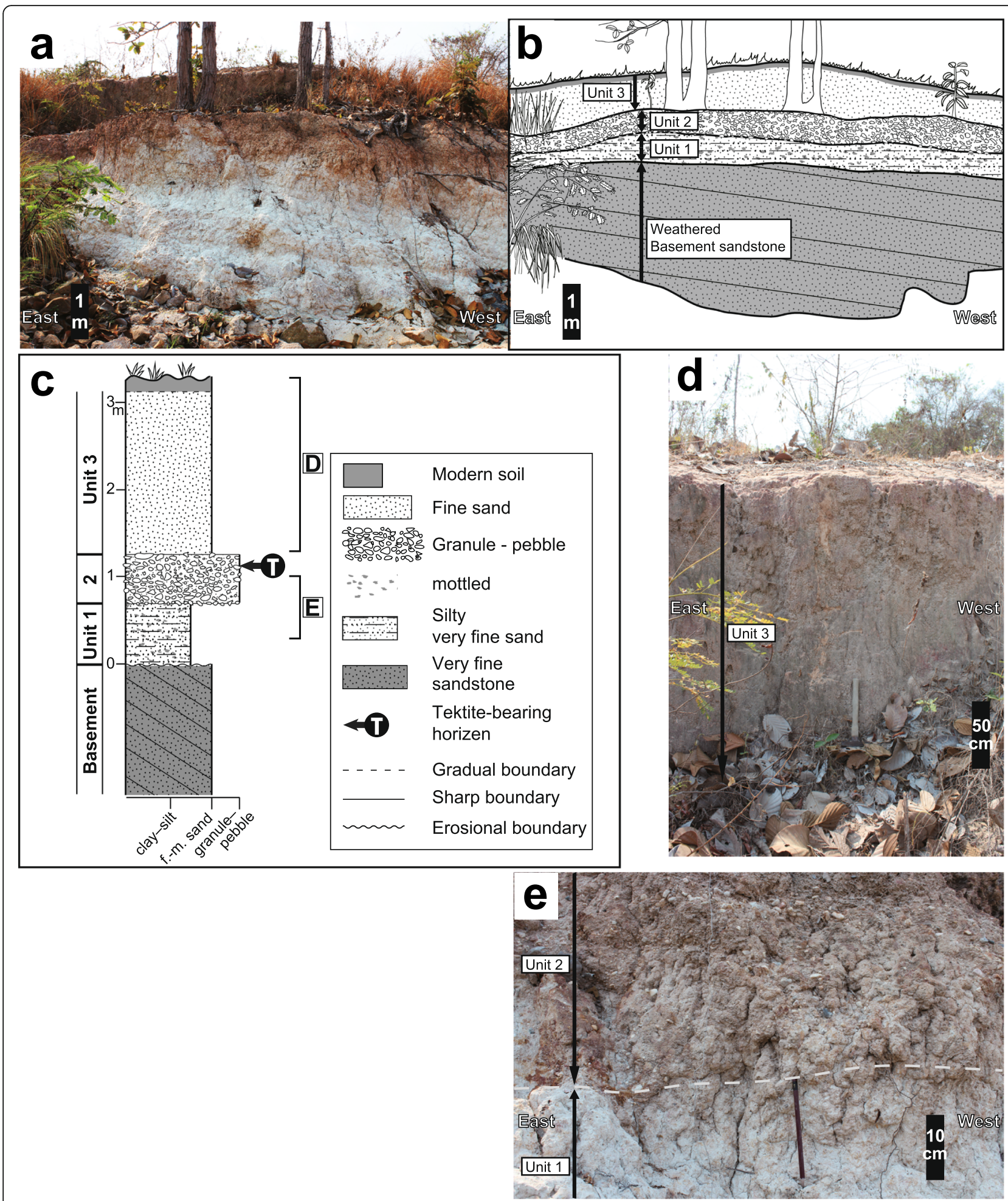

Fig. 3 Field photographs and columnar section of the HOO6 section. a field photograph of the section on the southern side of the spillway; $\mathbf{b}$ cartoon of the stratigraphy shown in $\mathbf{a}$. The legend $\mathbf{b}$ is the same as that for $\mathbf{c}$. $\mathbf{c}$ Columnar representation of the stratigraphy section made on the southern side where a good exposure was observed. Note the stratigraphic position of the MN tektite fragment cluster which was found in the upper part of Unit 2 on the northern side of the spillway. $\mathbf{d}$ Close photograph of Unit 3. e Close photograph of Unit 1 and Unit 2 

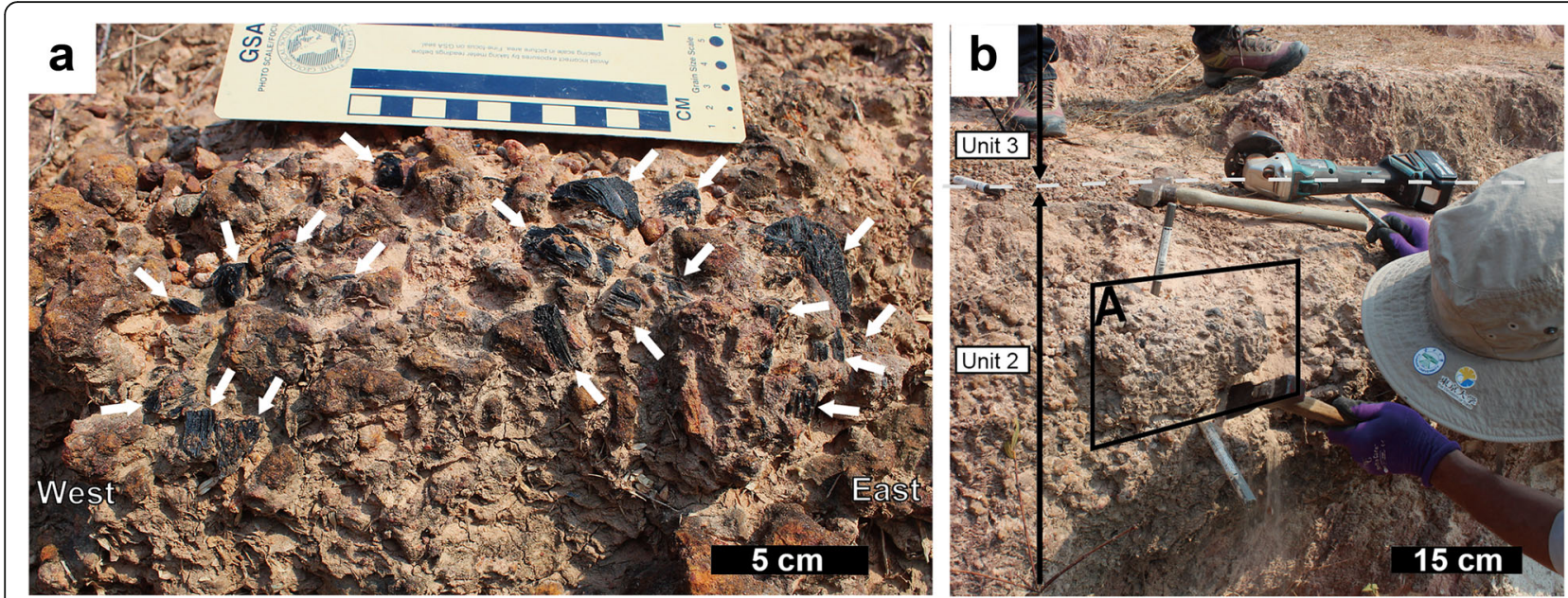

Fig. 4 Field photograph of the cluster of tektite fragments within the upper part of Unit 2. a The white allows point to each fragment partly exposed on the outcrop surface; $\mathbf{b}$ a wider photograph showing that the cluster of tektite fragments are $\mathrm{ca} .10 \mathrm{~cm}$ below the upper unit boundary

varies between 96 and $100 \mathrm{wt}$. \%, we used data, the total percentage of which is larger than $98 \%$, for calculating an average and standard deviation of major oxide composition for each thin section. After the data screening, each thin section still has ten to fifteen measured points. The standard deviation of major oxide compositions, which is $1.3 \%$ as a maximum (Table 2), includes variation due to heterogeneity of sample and uncertainty of measurement.

Consideration of the distribution of fragments sizes is often used to infer fragmentation processes (e.g., Farris and Paterson 2007; Bjørk et al. 2009; Roy et al. 2012). Fragmentation due to crushing or fracturing rock or glass leads to mass distributions that can be described by power law functions in which fragment frequency increases with a decrease in fragment size, due to scale invariance of the fragmentation process (e.g., Turcotte 1986). The relationship between fragment size and cumulative frequency can be represented by the power law equation

$$
N_{(\geq r)}=k r^{-D s}
$$

where $r$ is a radius of a fragment, $N_{(\geq \mathrm{r})}$ is the number of fragments with a radius greater than $r$, and $k$ is a fitting parameter. $D s$ is the fractal dimension for fragment size distribution.

The size and weight of each fragment was recorded in the laboratory. We measured the long, intermediate, and short axes ( $a, b$, and $c$ axes) defined as the dimensions of a fragment in three mutually orthogonal planes $(a>b>$ $c)$. The dimensions were measured using a caliper with an accuracy of $0.05 \mathrm{~mm}$.
The block sample was subjected to X-ray CT imaging using micro-CT scanner TESCO TXS320-ACTIS at the National Museum of Nature and Science, Tokyo. Each MN tektite fragment was separated using the segmentation editor in Amira 5.4.3 software based on the contrast of X-ray transmittance between tektite fragments and surrounding matrix. Because smaller tektite fragments are more difficult to recognize on CT images, we identified tektite fragments larger than $1 \mathrm{~cm}$. The identification of the tektite fragments in the $\mathrm{CT}$ images was confirmed by comparing each fragment to the tektite fragments collected from the dismantled block sample. In this study, only the preliminary result of observation of CT images is presented.

\section{Results and discussion}

\subsection{Description of the MN tektite fragments}

The MN tektite fragments found at the HO06 section are black in color, vesicular, and show submillimeterscale layering (Fig. 5). Under an optical microscope, thin sections of the fragments show layering composed of the dark-brownish-colored and light greenish-colored glass stripes, which are parallel to each other. Each stripe has $10-\mu \mathrm{m}$ scale subparallel lamination characterized by alternation of dark-brownish and pale greenish lenses. Elongated vesicles of submillimeter size, the long axes of which are roughly parallel to the layering, are occasionally observed (Fig. 6). Mineral inclusions which are several micrometers in diameter are sparsely contained, but they are too small to identify mineral species under an optical microscope. These characteristics are typical for MN Australasian tektites found in Indochina (e.g., Wasson 1991; Glass et al. 2020). 
Table 2 Major element compositions of the MN tektite fragments from the HOO6 section

\begin{tabular}{|c|c|c|c|c|c|c|c|c|c|c|}
\hline Sample & $\mathrm{SiO}_{2}(1 \sigma)$ & $\begin{array}{l}\mathrm{Al}_{2} \mathrm{O}_{3} \\
(1 \sigma)\end{array}$ & $\begin{array}{l}\mathrm{MgO} \\
(1 \sigma)\end{array}$ & $\mathrm{FeO}(1 \sigma)$ & $\mathrm{CaO}(1 \sigma)$ & $\begin{array}{l}\mathrm{Na}_{2} \mathrm{O} \\
(1 \sigma)\end{array}$ & $\mathrm{K}_{2} \mathrm{O}(1 \sigma)$ & $\begin{array}{l}\mathrm{MnO} \\
(1 \sigma)\end{array}$ & $\mathrm{TiO}_{2}(1 \sigma)$ & Total $(1 \sigma)$ \\
\hline HO06MN16 & $\begin{array}{l}79.29 \\
(1.30)\end{array}$ & $9.64(0.62)$ & $\begin{array}{l}1.25 \\
(0.14)\end{array}$ & $\begin{array}{l}3.63 \\
(0.29)\end{array}$ & $\begin{array}{l}1.10 \\
(0.15)\end{array}$ & $1.01(0.07)$ & $\begin{array}{l}2.27 \\
(0.10)\end{array}$ & $\begin{array}{l}0.09 \\
(0.06)\end{array}$ & $\begin{array}{l}0.56 \\
(0.08)\end{array}$ & $98.84(0.53)$ \\
\hline HO06MN79 & $\begin{array}{l}78.52 \\
(2.90)\end{array}$ & $\begin{array}{l}10.29 \\
(1.76)\end{array}$ & $\begin{array}{l}1.46 \\
(0.31)\end{array}$ & $\begin{array}{l}3.70 \\
(0.58)\end{array}$ & $\begin{array}{l}1.00 \\
(0.19)\end{array}$ & $1.03(0.14)$ & $\begin{array}{l}2.27 \\
(0.09)\end{array}$ & $\begin{array}{l}0.08 \\
(0.05)\end{array}$ & $\begin{array}{l}0.62 \\
(0.08)\end{array}$ & $98.97(0.62)$ \\
\hline HO06MN105 & $\begin{array}{l}79.56 \\
(1.25)\end{array}$ & $9.72(0.85)$ & $\begin{array}{l}1.37 \\
(0.18)\end{array}$ & $\begin{array}{l}3.61 \\
(0.32)\end{array}$ & $\begin{array}{l}0.89 \\
(0.14)\end{array}$ & $0.96(0.12)$ & $\begin{array}{l}2.30 \\
(0.13)\end{array}$ & $\begin{array}{l}0.07 \\
(0.05)\end{array}$ & $\begin{array}{l}0.61 \\
(0.06)\end{array}$ & $99.11(0.45)$ \\
\hline HO06MN119 & $\begin{array}{l}80.18 \\
(1.27)\end{array}$ & $9.19(0.93)$ & $\begin{array}{l}1.20 \\
(0.13)\end{array}$ & $\begin{array}{l}3.45 \\
(0.40)\end{array}$ & $\begin{array}{l}1.21 \\
(0.08)\end{array}$ & $0.97(0.08)$ & $\begin{array}{l}2.13 \\
(0.14)\end{array}$ & $\begin{array}{l}0.09 \\
(0.06)\end{array}$ & $\begin{array}{l}0.58 \\
(0.05)\end{array}$ & $99.01(0.59)$ \\
\hline HO06MN121 & $\begin{array}{l}79.46 \\
(1.02)\end{array}$ & $9.86(0.74)$ & $\begin{array}{l}1.37 \\
(0.10)\end{array}$ & $\begin{array}{l}3.58 \\
(0.20)\end{array}$ & $\begin{array}{l}1.14 \\
(0.07)\end{array}$ & $0.92(0.06)$ & $\begin{array}{l}2.34 \\
(0.08)\end{array}$ & $\begin{array}{l}0.11 \\
(0.07)\end{array}$ & $\begin{array}{l}0.58 \\
(0.04)\end{array}$ & $99.36(0.53)$ \\
\hline HO06MN122 & $79.6(1.07)$ & $9.46(0.64)$ & $\begin{array}{l}1.33 \\
(0.09)\end{array}$ & $\begin{array}{l}3.44 \\
(0.32)\end{array}$ & $\begin{array}{l}1.17 \\
(0.13)\end{array}$ & $0.98(0.06)$ & $\begin{array}{l}2.17 \\
(0.19)\end{array}$ & $\begin{array}{l}0.10 \\
(0.07)\end{array}$ & $\begin{array}{l}0.55 \\
(0.07)\end{array}$ & $98.85(0.51)$ \\
\hline HO06MN124 & $\begin{array}{l}79.54 \\
(0.80)\end{array}$ & $9.59(0.60)$ & $\begin{array}{l}1.14 \\
(0.09)\end{array}$ & $\begin{array}{l}3.48 \\
(0.29)\end{array}$ & $\begin{array}{l}0.80 \\
(0.04)\end{array}$ & $1.03(0.05)$ & $\begin{array}{l}2.27 \\
(0.11)\end{array}$ & $\begin{array}{l}0.10 \\
(0.06)\end{array}$ & $\begin{array}{l}0.56 \\
(0.08)\end{array}$ & $98.51(0.43)$ \\
\hline HO06MN129 & $\begin{array}{l}79.36 \\
(1.13)\end{array}$ & $9.61(0.56)$ & $\begin{array}{l}1.22 \\
(0.19)\end{array}$ & $\begin{array}{l}3.50 \\
(0.38)\end{array}$ & $\begin{array}{l}1.19 \\
(0.09)\end{array}$ & $1.00(0.05)$ & $\begin{array}{l}2.31 \\
(0.10)\end{array}$ & $\begin{array}{l}0.11 \\
(0.07)\end{array}$ & $\begin{array}{l}0.57 \\
(0.06)\end{array}$ & $98.86(0.57)$ \\
\hline HO06MN141 & $\begin{array}{l}79.17 \\
(1.33)\end{array}$ & $9.87(0.90)$ & $\begin{array}{l}1.22 \\
(0.16)\end{array}$ & $\begin{array}{l}3.52 \\
(0.28)\end{array}$ & $\begin{array}{l}0.86 \\
(0.10)\end{array}$ & $0.98(0.07)$ & $\begin{array}{l}2.32 \\
(0.05)\end{array}$ & $\begin{array}{l}0.10 \\
(0.04)\end{array}$ & $\begin{array}{l}0.63 \\
(0.07)\end{array}$ & $98.69(0.25)$ \\
\hline Average & $\begin{array}{l}79.41 \\
(0.42)\end{array}$ & $9.69(0.29)$ & $\begin{array}{l}1.29 \\
(0.10)\end{array}$ & $\begin{array}{l}3.55 \\
(0.09)\end{array}$ & $\begin{array}{l}1.04 \\
(0.15)\end{array}$ & $0.99(0.03)$ & $\begin{array}{l}2.27 \\
(0.07)\end{array}$ & $\begin{array}{l}0.10 \\
(0.01)\end{array}$ & $\begin{array}{l}0.58 \\
(0.03)\end{array}$ & $98.91(0.23)$ \\
\hline Koeberl $1992(n=19)$ & $\begin{array}{l}78.95 \\
(1.52)\end{array}$ & $\begin{array}{l}10.19 \\
(0.98)\end{array}$ & $\begin{array}{l}1.43 \\
(0.13)\end{array}$ & $\begin{array}{l}3.75 \\
(0.35)\end{array}$ & $\begin{array}{l}1.21 \\
(0.15)\end{array}$ & $0.92(0.09)$ & $\begin{array}{l}2.42 \\
(0.10)\end{array}$ & $\begin{array}{l}0.08 \\
(0.01)\end{array}$ & $\begin{array}{l}0.63 \\
(0.05)\end{array}$ & $99.59(0.25)$ \\
\hline Fiske et al. $1996(n=3)$ & $\begin{array}{r}79.83 \\
(0.15)\end{array}$ & $9.11(0.15)$ & $\begin{array}{l}1.51 \\
(0.03)\end{array}$ & $\begin{array}{l}3.39 \\
(0.04)\end{array}$ & $\begin{array}{l}1.46 \\
(0.03)\end{array}$ & $1.52(0.04)$ & $\begin{array}{l}2.27 \\
(0.02)\end{array}$ & $\begin{array}{l}0.09 \\
(0.00)\end{array}$ & $\begin{array}{l}0.61 \\
(0.01)\end{array}$ & $99.78(0.24)$ \\
\hline Herzog et al. $2008(n=2)$ & $\begin{array}{l}78.56 \\
(0.35)\end{array}$ & $\begin{array}{l}11.02 \\
(0.19)\end{array}$ & $\begin{array}{l}1.71 \\
(0.01)\end{array}$ & $\begin{array}{l}4.10 \\
(0.06)\end{array}$ & $\begin{array}{l}1.65 \\
(0.01)\end{array}$ & $0.80(0.03)$ & $\begin{array}{l}2.45 \\
(0.01)\end{array}$ & $\begin{array}{l}0.07 \\
(0.03)\end{array}$ & $\begin{array}{l}0.70 \\
(0.01)\end{array}$ & $\begin{array}{l}101.05 \\
(0.06)\end{array}$ \\
\hline $\begin{array}{l}\text { Glass and Koeberl } 1989(n= \\
\text { 1) }\end{array}$ & 79.2 & 10.3 & 1.41 & 3.76 & 1.09 & 0.87 & 2.44 & 0.09 & 0.62 & 99.78 \\
\hline
\end{tabular}

Three-hundred and thirty-one MN tektite fragments were found in the small $(\sim 40 \mathrm{~cm} \times 30 \mathrm{~cm})$ area with 10 $\mathrm{cm}$ in thickness in the upper part of Unit 2 (Fig. 4) (One-hundred and seventy-seven fragments were recovered in the field after taking the block sample, and 154 fragments were recovered in the laboratory from the dismantled block sample.) The total weight of the 331 fragments is $713 \mathrm{~g}$.

The length of $a, b$, and $c$ axes of the fragments ranges from 2.00 to $52.80 \mathrm{~mm}, 1.95$ to $40.00 \mathrm{~mm}$, and 0.70 to $30.80 \mathrm{~mm}$, respectively. The average length and standard deviation (in parenthesis) are 16.3 (8.7), 11.3 (7.1), and $7.2(5.5) \mathrm{mm}$, respectively. These large standard deviations of the size of the tektite fragments correspond to "very poor sorting" in the scale of sorting for sediments (Folk and Ward 1957). The fragments are very angular, and fragile edges are well preserved, as shown in Fig. 5. Forty-six large fragments recovered from inside the block sample and seven large fragments recovered in the field after taking the block sample (53 tektite fragments in total) are fitted together to form a large MN tektite mass of $\sim 370 \mathrm{~g}$ that shows an ellipsoidal shape (Fig. 7a). The rest of the fragments are too small and so many that it is difficult to find their positions to conduct restoration of the original tektite mass. However, the preliminary restoration result strongly suggests that tektite fragments forming the cluster composed one large tektite mass of $>713 \mathrm{~g}$ weight before the landing. The majority of the outermost part of the restored tektite mass was peeled off showing the section of the internal layered structure (Fig. 7b), while a typical pitted and grooved surface similar to that in splash-form tektites was preserved in some part (Fig. 7c) suggesting the original surface of the tektite mass was preserved. The fracture surfaces of the MN tektite fragments from $\mathrm{HO} 06$ are matt compared to a fresh fracture surface due to the presence of small pits, as shown in Fig. $7 d$. These matt surfaces of the tektites were formed by soil etching after their burial (Rost 1969; La Marche et al. 1984), suggesting that fracturing occurred in the geological past. Nearly all fragments have iron-oxide cement and calcite cement in some cases adhering to some of the fragment surfaces, and some vesicles open to the surface are filled with the iron-oxide and calcite cement materials indicating that the laterization of Unit 2 occurred after their fragmentation. 

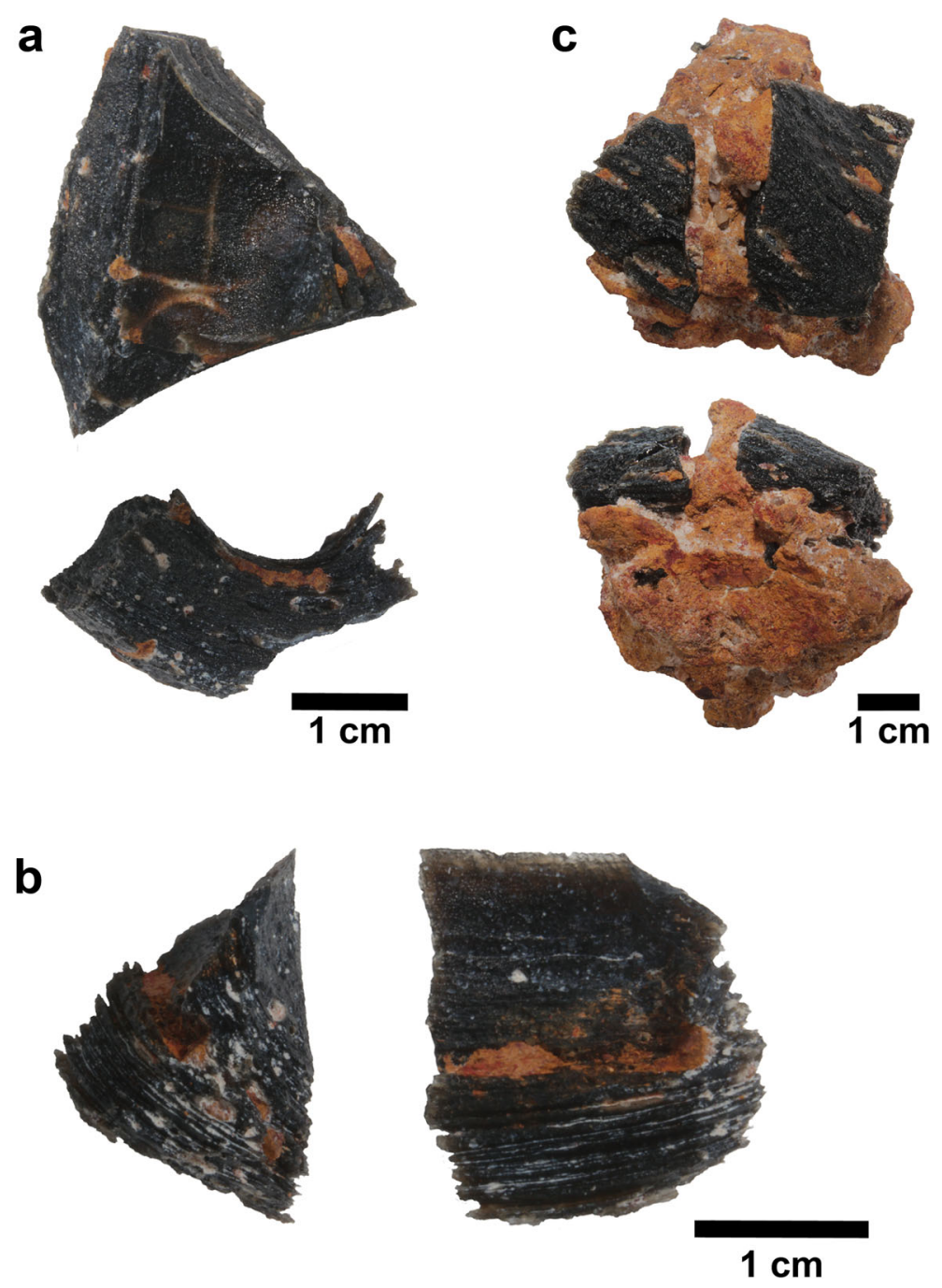

Fig. 5 Photographs taken of differing orientations of examples of the tektite fragments recovered from HO06 section. a Sample HO06MN34. b Sample HO06MN79. c Sample HO06MN32_a and 32_b. The MN tektite fragments are black vesicular glass showing layering structure and have angular shapes with fragile edges

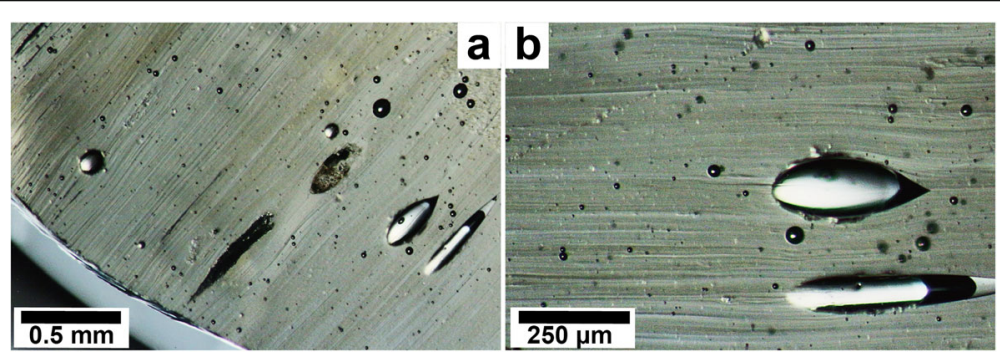

Fig. 6 Thin section photographs of sample HO06MN12 (the contrast of the photographs is enhanced). The layering texture is composed of the dark- and light-colored glass lenses, and the elongated vesicles are shown. a Lower magnification view showing submillimeter-scale alteration of dark and light stripes. $\mathbf{b}$ Higher magnification view of the same section in $\mathbf{a}$ 


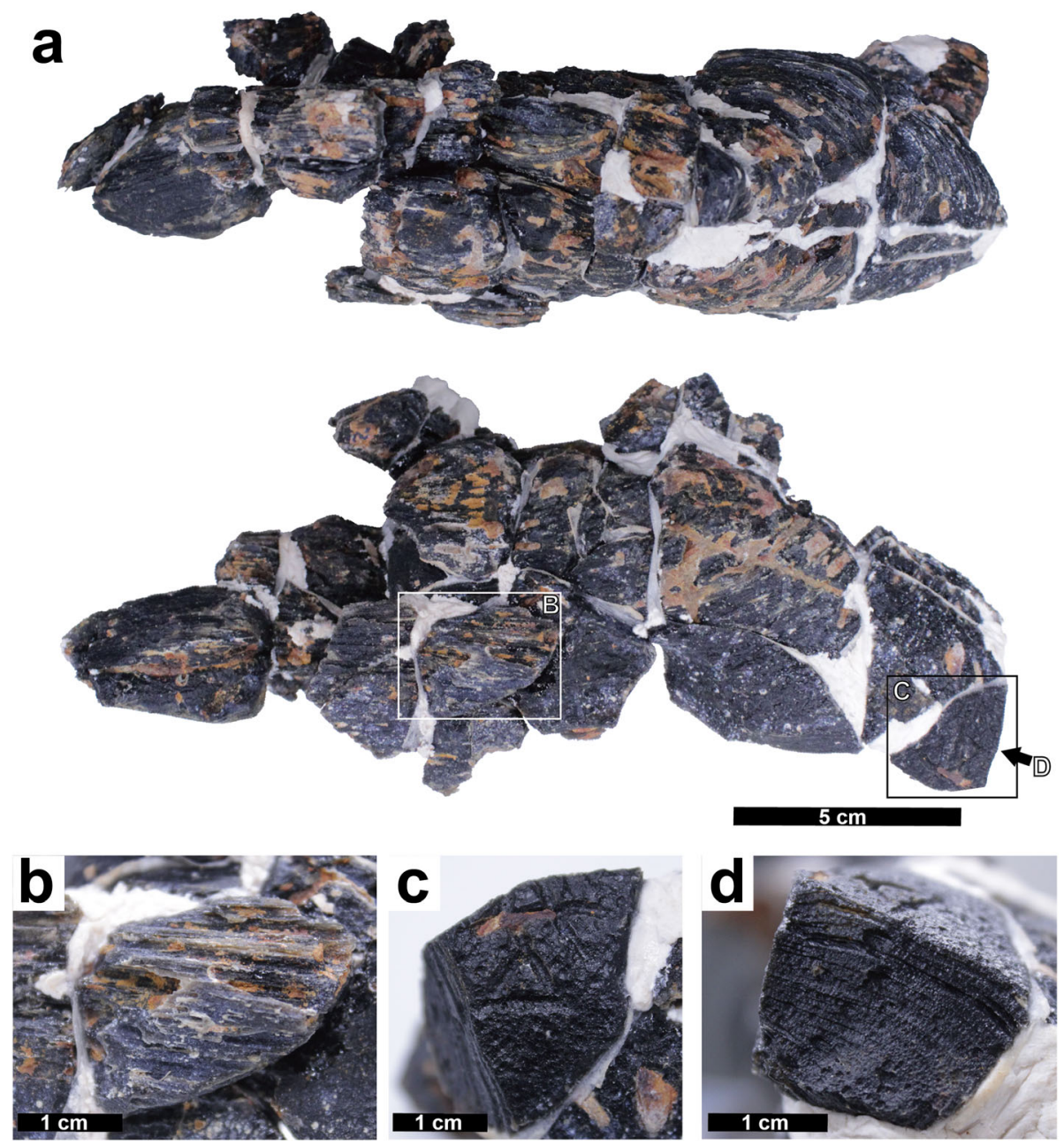

Fig. 7 The photographs taken of differing orientations of the restored tektite mass. $\mathbf{b}$ Photograph of a part of the surface which was peeled off showing the section of the internal layered structure cut by low angle. $\mathbf{c}$ Photograph of a part of the surface which is considered as the preserved original surface of the tektite mass showing a typical pitted and grooved surface. $\mathbf{d}$ Photograph of the fracture surface of the MN tektite fragment, which is matt due to the presence of small pits

The fact that most of large tektite fragments recovered from the block sample fitted together to form a large ellipsoidal tektite mass with the original surface partly preserved indicates the tektite fragments were formed as a result of the fragmentation of one large tektite mass. The very poorly sorted nature of the MN tektite fragments, the very angular shapes with well-preserved fragile edges, and the occurrence of tektite fragments forming a cluster suggest that these MN tektite fragments were not transported a long distance but rather fragmented in situ.

\subsection{Major element composition}

The major element compositions of all nine $\mathrm{MN}$ tektite fragments from the HOO6 section, together with their average compositions and standard deviations, are given in Table 2. The major element compositions of these samples fall within the range of compositions of previous analyses of MN tektites from Ubon Ratchathani province within $1 \sigma$, for most elements (Glass and Koeberl 1989; Koeberl 1992; Fiske et al. 1996; Herzog et al. 2008) (Fig. 8a), indicating that they are not distinguishable chemically from previously reported Australasian MN tektites from Ubon Ratchathani province.

Figure 8b shows $\mathrm{SiO}_{2}$ vs $\mathrm{Al}_{2} \mathrm{O}_{3}, \mathrm{FeO}, \mathrm{K}_{2} \mathrm{O}$, and $\mathrm{MgO}$ values for the nine MN tektite fragments from the HO06 section plotted with values reported for other Australasian MN tektites from Ubon Ratchatani province (Glass and Koeberl 1989; Koeberl 1992; Fiske et al. 1996; Herzog et al. 2008). The major element composition of the nine fragments is closely plotted in a narrow area and indistinguishable from each other within $1 \sigma$. This narrow range of the major element composition of the nine fragments is consistent with the idea that the 


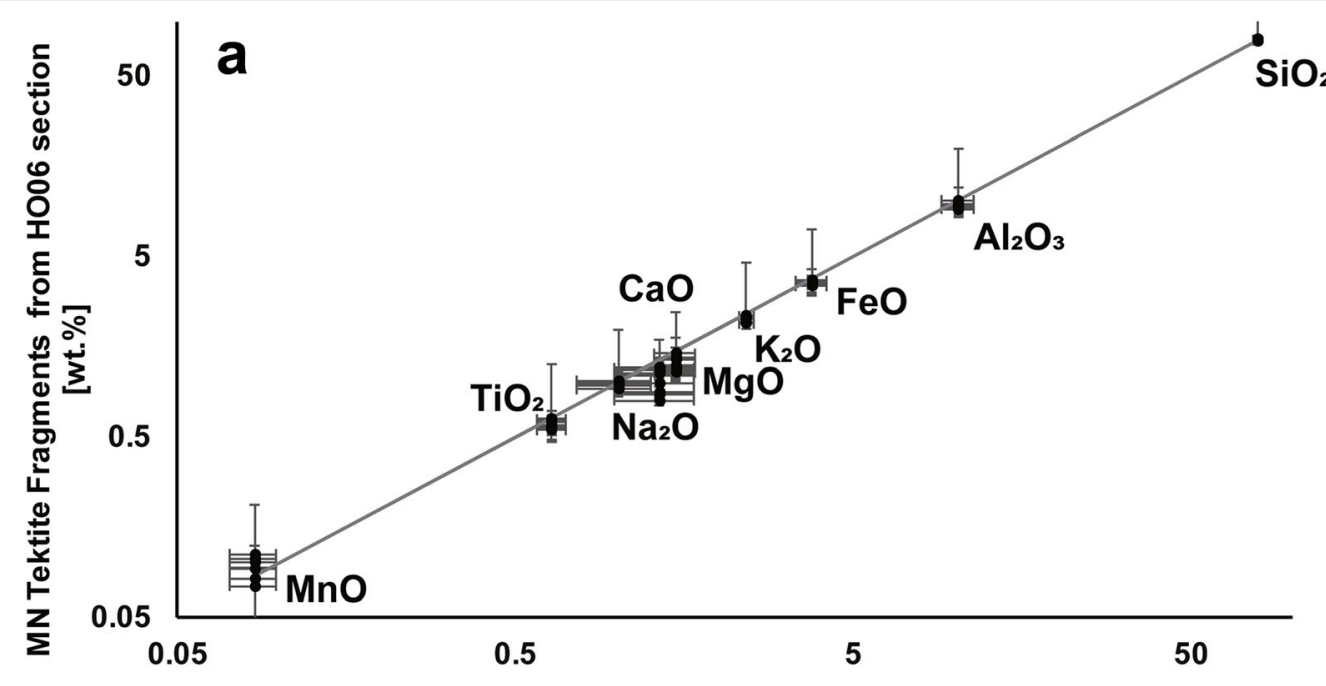

Average of 25 MN Tektites from Ubon Ratchathani, NE Thailand [wt.\%]

(Glass and Koeberl 1989; Koeberl 1992; Fiske et al. 1996; Herzog et al. 2008)
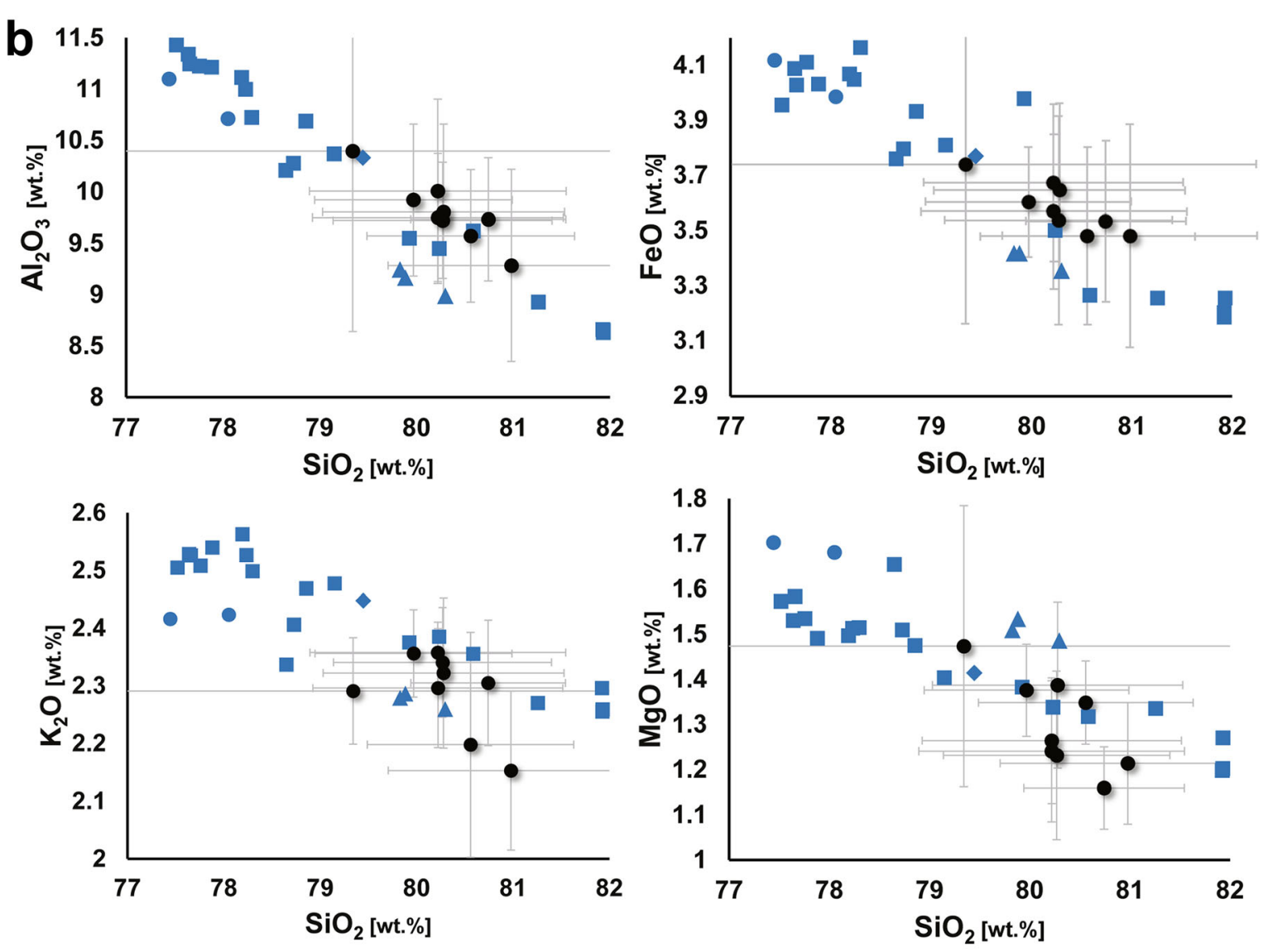

$$
\begin{aligned}
& \text { MN tektite fragments (This study) } \\
& \text { MN tektites from Ubon Ratchathani } \\
& \text { Koeberl (1992) } \quad \text { Fiske et al. (1996) Herzog et al. (2008) Glass and Koeberl (1989) }
\end{aligned}
$$


(See figure on previous page.)

Fig. 8 Major element compositions of the MN tektite fragments from the HOO6 section. a Comparison of the major element compositions of the MN tektite fragments from the $\mathrm{HOO}$ section and the average of other MN tektites from the same region, Ubon Ratchathani province, previously reported. $\mathbf{b} X-Y$ plots of the concentrations of $\mathrm{SiO}_{2}$ versus $\mathrm{Al}_{2} \mathrm{O}_{3}, \mathrm{FeO}, \mathrm{K}_{2} \mathrm{O}$, and $\mathrm{MgO}$ of the $\mathrm{MN}$ tektite fragments from the HOO6 section compared with other MN tektites from the same region, Ubon Ratchathani province, previously reported by Koeberl (1992), Fiske et al. (1996), Herzog et al. (2008), and Glass and Koeberl (1989). The error bars represent $1 \sigma$ of ten to fifteen measurements of each section

MN tektite fragments collected at HO06 section originally formed one large MN tektite mass.

\subsection{Size distribution of the $\mathrm{MN}$ tektite fragments}

$D s$ for the fragments generated by fragmentation of rocks or glass is proportional to the intensity of fracturing in which fragments generated by higher magnitude and rate of stress loading tend to have higher value of $D s$, although $D s$ is affected also by the inherent strength properties of the rock or glass (e.g., Takagi et al. 1984; Jébrak 1997; Roy et al. 2012; Xu 2018). For instance, Ds for rock fragments generated by weathering of andesite in the field and hammering of a limestone cube by hand is 2.5-2.7 (calculated from the data of Domokos et al. 2015), and that for rock fragments generated by rockfalls and rock avalanches with various lithology ranges from 1.6 to 4.7 (Crosta et al. 2007; Ruiz-Carulla and Corominas, 2020). Rock fragments generated by complete fragmentation of target rocks in hypervelocity impact experiments show bi- or tri-fractal distributions in which $D s$ for the finer fraction is 1.7 to 4.3 and $D s$ for the coarser fraction is 4.8 to 11.9 (calculated from the data of Takagi et al. 1984; Michikami et al. 2016). The $D s$ for fragments of a block on the Moon fragmented by a small meteorite impact is around or higher than 4 (Ruesch et al. 2020).

Figure 9 shows the cumulative size distribution of the MN tektite fragments at HO06 section. The size of the fragment is represented by the length of its equivalent spherical diameter $(r=\sqrt[3]{a b c})$. The cumulative size dis- tribution increases rapidly from 37 to $26 \mathrm{~mm}$ and then increases slowly in a range smaller than $26 \mathrm{~mm}$. It shows a bi-fractal distribution described by two power laws in the range from 10 to $26 \mathrm{~mm}$ and from 26 to $37 \mathrm{~mm}$, with $D s$ of 2.2 and 7.5, respectively. The position of the point dividing the two power laws is calculated by adjusting the dividing point every $0.5 \mathrm{~cm}$ to maximize the average of the $R^{2}$ values. The bi-fractal distribution of fragment size implies that the size distribution of the fragments was affected by two different fragmentation mechanisms (e.g., Schultz and Gault 1990). Although the effect of the difference of physical properties between the tektite glass and rocks need to be considered, the high $D s$ value (7.5) for the coarse fraction of the tektite fragments is larger than the range of $D s$ previously reported for rock fragments generated by rockfalls and rock avalanches (1.6-4.7; Crosta et al. 2007; RuizCarulla and Corominas 2020) and similar to the $D s$ for the coarser fraction fragments generated by hyperspeed impact experiments (4.8-11.9; calculated from the data of Takagi et al. 1984; Michikami et al. 2016) and impact fragmentation on the Moon (3.3-6; Ruesch et al. 2020), suggesting that the tektite fragments were formed through intense fragmentation by a relatively high energetic process.

Based on the close spatial association of the MN tektite fragments at Huai Sai, Fiske et al. (1996) proposed that the fragmentation of an original MN tektite mass was a low-energy process such as weather or climaterelated temperature-induced fracturing after the deposition of the MN tektite mass. However, as is mentioned

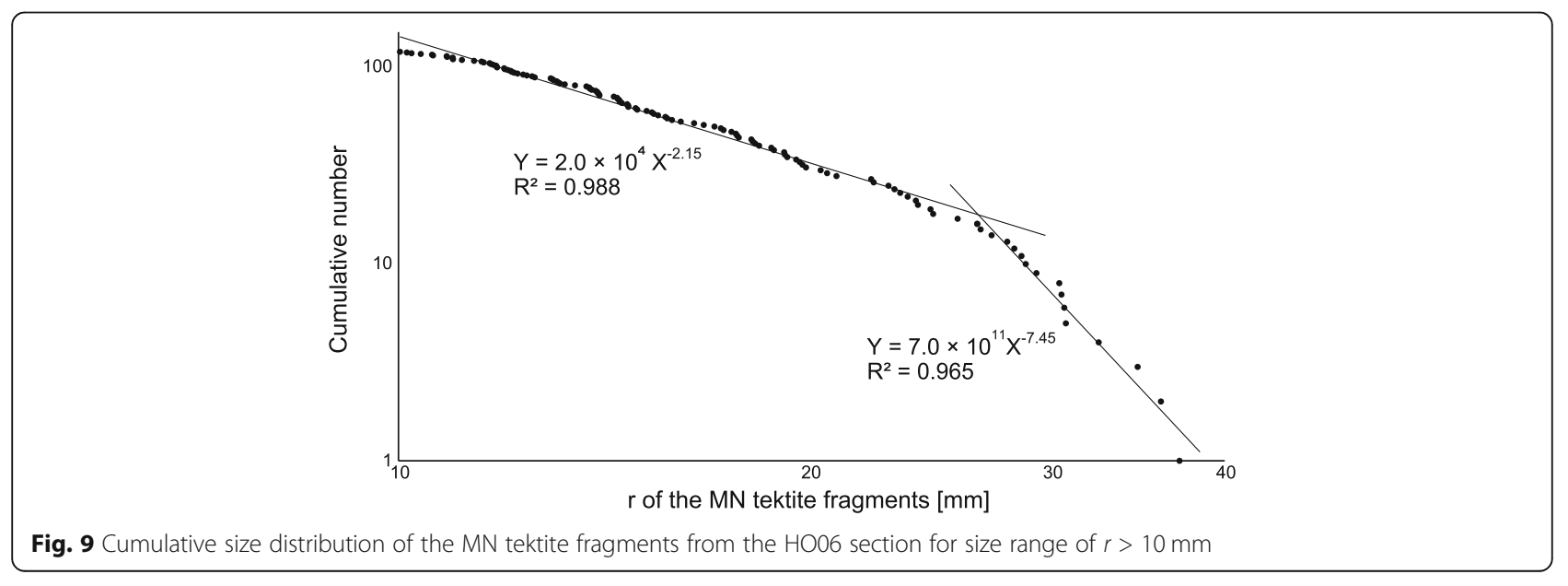


above, the size distribution of the coarse fraction of the MN tektite fragments from HO06 section measured in this study suggests a relatively high-energy process rather than a low-energy process such as weather or climate-related temperature-induced fracturing. The possibility that the MN tektite mass was broken by tectonic movement after deposition is also unlikely because we did not see any evidence of tectonic deformation at the outcrop. The other possibility is that the fragmentation occurred during the flight by high-speed collision of ejecta materials before the deposition. However, this possibility is also unlikely because if the fragmentation occurred during the flight, the fragments would have separated before they landed on the ground and would not have formed a cluster. Consequently, the timing of the fragmentation of the MN tektite mass is constrained to the time of the landing on the ground. We propose that an original tektite mass was fragmented by collision of the MN tektite mass with the ground. Either the MN tektite fragments were considered to have been codeposited with other ejecta materials immediately after (or almost the same time) the fragmentation or the MN tektite mass was fragmented during penetration into the unconsolidated ejecta of Unit 2 so that the fragments remained as a cluster.

As for the fragmentation mechanism for the finer fraction of the MN tektite fragments, one possibility is that some of the tektite fragments were further fractured by weather or climate-related thermal fracturing after the deposition. Another possibility is that some of the tektite fragments generated by the collision of the original tektite mass with the ground surface were secondarily fractured by collision with the surrounding other ejecta materials immediately after the first fragmentation, resulting in the bi-fractal size distribution of the tektite fragments. In any case, the whole size distribution of the tektite fragments, especially the high $D s$ value for the coarse fraction, is different from the size distributions of rock fragments generated by low-energy processes.

\subsection{Preliminary observation of CT scan 3D image of the block sample}

In CT cross-section images, tektite fragments appear as angular-shaped areas with moderate X-ray transmittance, exhibiting elongated vesicles. The preliminary CT scan 3D image observation of the block sample revealed that the MN tektite fragments are distributed in $20 \times 10$ $\times 10 \mathrm{~cm}$ space as if they were expanded from the original tektite mass by fragmentation. This distribution of the tektite fragments suggests either that the tektite fragments were buried immediately after fragmentation on landing by co-deposited other ejecta materials of Unit 2 or that fragmentation occurred during the tektite mass penetrated into the ground cover of unconsolidated ejecta (granule to pebble-bearing sand) of Unit 2 so that tektite fragments have not been spread significantly. This distribution of the tektite fragments is inconsistent with the previous interpretation in which these tektites were considered to have been reworked on the paleo surface because if reworked on the paleo surface, the fragments would be distributed on a plane.

\subsection{Stratigraphic position of MN Australasian tektite in Indochina}

As is proposed in the previous sections, the fragmentation of the MN tektite mass occurred at the time of the landing on the ground, and either the fragments were buried immediately with other ejecta materials or the tektite mass penetrated into the ground covered by unconsolidated ejecta deposit and fragmented within the ejecta. In either case, the fragments were preserved as a cluster. Thus, the MN tektite fragments in the upper part of Unit 2 ("laterite" layer) at the HO06 section are considered as in primary position.

Fiske et al. (1996) considered that layered tektites found at the top of Unit 2 at the Huai Om and Huai Sai sections to be reworked because, in their opinion, the top of Unit 2 represents a paleo-erosional surface. However, the fact that $\mathrm{MN}$ tektite fragments are found not at the top of the "laterite" layer but within the "laterite" layer at the HOO6 section does not support this interpretation. Also, there was no evidence of erosion at the top of Unit 2 at the nearby Huai Om section (Tada et al. 2019) as well as several other sections in the region. Furthermore, our field observation of the "laterite" layer in other localities (for example, an active sand pit at Noen Sa-nga in Chaiyaphum province) suggests that laterization (precipitation of iron hydroxides) of this layer can occur within a few years after road cuts and pit walls were formed, indicating that the hard-cemented appearance of the "laterite" layer was not formed as an erosional pavement before the impact, but formed on the outcrop surface by recent ferricretization (Fig. S2). Koeberl and Glass (2000) and Keates (2000) pointed out that the Australasian tektites in Australia generally are found in deposits younger than the age of the impact, and interpreted by analogy that the tektites in Indochina may be of similar reworked origin. However, this analogy is not based on observational evidence. It should also be considered that dating of Quaternary sediments in Indochina is replete with methodological difficulties that may result in young ages being reported for strata that are considerably older (Carling et al. 2020).

The in situ occurrence of the MN tektite fragments in Unit 2 at the HO06 section supports the idea that the Quaternary depositional sequence of Units 1-3 in this region is an ejecta deposit of the Australasian tektite event based on the finding of shocked quartz from Units 1-3 at Huai Om section (Tada et al. 2019). The fact that 
both the $\mathrm{MN}$ and splash-form tektites generally were found in the upper part of or at the top of the "laterite" layer at sites in the wide area of eastern Indochina (Table 1, Fig. 1) further supports the idea that the Australasian tektites found from the "laterite" layer were deposited in situ as an ejecta.

\section{Conclusions}

We described in detail the occurrence of a cluster of MN tektite fragments found at the HO06 section, Ubon Ratchathani province, northeastern Thailand. At least 331 fragments of MN tektite with a total weight of $713 \mathrm{~g}$ were concentrated in a small $(40 \times 30 \mathrm{~cm})$ area within the upper part of a sandy gravel layer corresponding to the "laterite" layer. The occurrence as a cluster, the very angular shapes and the very poorly sorted nature of the fragments, the restoration of larger tektite fragments into one ellipsoidal MN tektite mass, and the similar chemical composition of the fragments suggest that these MN tektite fragments were not transported in long distances but rather fragmented in situ at the landing from a ballistic trajectory. This conclusion is contrary to the previous interpretation that similar tektite fragments were reworked on the upper surface of the "laterite" layer which was interpreted as the paleoerosional surface (Fiske et al. 1996).

The size distribution of the MN tektite fragments is bifractal following two power laws in the range from 10 to $26 \mathrm{~mm}$ and from 26 to $37 \mathrm{~mm}$ in $r$, respectively, with $D s$ of 2.2 and 7.5. The high $D s$ value for the coarse fraction of the tektite fragments is larger than the range of $D s$ previously reported for rock fragments generated by rockfalls and rock avalanches and similar to $D s$ for the coarser fraction fragments generated by hyperspeed impact experiments, suggesting that the tektite fragments were formed through intense fragmentation by a relatively high energetic process at the landing on the ground.

\section{Supplementary information}

Supplementary information accompanies this paper at https://doi.org/10. 1186/s40645-020-00378-4.

Additional file 1:. Supplementary Information.

\section{Abbreviations}

AATE: Australasian Tektite Event; 3D: Three dimensions; CT: Computed tomography; MN: Muong Nong-type; EPMA: Electron probe microanalysis; Ds: Fractal dimension; $r$ : equivalent spherical diameter

\section{Acknowledgments}

We sincerely thank Pratueng Jintasakul, the director of Khorat Fossil Museum, and Pakkaporn Singhwachiraworakul for their hospitality during the field survey. We would also like to thank Hideto Yoshida for his help in the electron microprobe analyses. We are much obliged to Chisako Sakata and Manabe Makoto for conducting the CT scanning of the block sample. We are grateful to Takanobu Tsuihiji, Seisiro Tada, Ayano Mizukami, Noriyuki Wakimizu, Kazuko Yoshizawa, and Hirochika Ueda for their kind help on the analysis of the CT scan images.

\section{Authors' contributions}

$P A C, R T$, and $\Pi$ designed the study and planned the field survey. $\Pi, R T$, PAC, WS, and PC conducted the field survey. PC found the cluster of the tektite fragments in the field. TT, PC, and RT took the samples, and $\Pi T$ conducted all the measurements. ET helped in interpreting the data and revising the manuscript. $\Pi \mathrm{d}$ drew the figures and tables and wrote a draft of the manuscript. RT, ET, and PAC supervised TT. The authors read and approved the final manuscript.

\section{Funding}

This study was supported by the Japan Society for the Promotion of Science (JSPS) KAKENHI Fostering Joint International Research (B) 18KK0092 (20182021) to R. Tada, and the Fujiwara Natural History Foundation Grant in 2016 and Grant-in-aid for JSPS Research Fellow Number $19 \mathrm{~J} 13252$ awarded to T. Tada. P. A. Carling held a Leverhulme Emeritus Fellowship (2016-2018) which directly supported the project.

\section{Availability of data and materials}

The datasets used and/or analyzed during the current study are available from the corresponding author on request.

\section{Competing interests}

The authors declare that they have no competing interests.

\section{Author details}

${ }^{1}$ Department of Earth and Planetary Science, The University of Tokyo, 7-3-1 Hongo, Bunkyo-Ku, Tokyo 113-0033, Japan. ${ }^{2}$ Institute for Geo-Cosmology, Chiba Institute of Technology, 2-17-1 Tsudanuma, Narashino, Chiba 275-0016, Japan. ${ }^{3}$ Research Center for Earth System Science, Yunnan University, Chenggong District, Kunming 650500, PR China. ${ }^{4}$ Northeastern Research Institute of Petrified Wood \& Mineral Resources, Nakhon Ratchasima Rajabhat University, Baan Kroke Duen Ha, Suranaree Sub-district, Muang Nakhon Ratchasima District, Nakhon Ratchasima 30000, Thailand. ${ }^{5}$ School of Geography and Environmental Science, University of Southampton, University Road, Southampton SO17 1BJ, UK.

Received: 6 July 2020 Accepted: 29 September 2020

Published online: 08 November 2020

\section{References}

Barnes VE, Pitakpaivan K (1962) Origin of Indochinite tektites. Proc Natl Acad Sci 48(6):947-955

Bjørk TE, Mair K, Austrheim H (2009) Quantifying granular material and deformation: advantages of combining grain size, shape, and mineral phase recognition analysis. J Struct Geol 31(7):637-653. https://doi.org/10.1016/j.jsg. 2009.03.020

Carling PA, Tada T, Tada R, Songtham W, Cresswell A, Sanderson D, Porat N, Duangkrayom J, Meshkova L, Croudace I, Darby S, Fan X (2020) Regionallyextensive ejecta layer of the Australian tektite strewn-field: the MIS 20 large meteorite impact in Indochina. Presented at the JpGU-AGU joint meeting 2020, 12-16 July 2020.

Crosta GB, Frattini P, Fusi N (2007) Fragmentation in the Val Pola rock avalanche, Italian Alps. J Geophys Res 112(1):1-23. https://doi.org/10.1029/2005JF000455

Domokos G, Kun F, Sipos AA, Szabó T (2015) Universality of fragment shapes. Sci Rep 5:9147. https://doi.org/10.1038/srep09147

Farris DW, Paterson SR (2007) Contamination of silicic magmas and fractal fragmentation of xenoliths in Paleocene plutons on Kodiak Island, Alaska. Can Mineral 45(1):107-129. https://doi.org/10.2113/gscanmin.45.1.107

Fiske PS, Putthapiban P, Wasson JT (1996) Excavation and analysis of layered tektites from Northeast Thailand: results of 1994 field expedition. Meteorit Planet Sci 31:36-41

Fiske PS, Schnetzlerz C, Mchone J, Kham K (1999) Layered tektites of Southeast Asia: field studies in Central Laos and Vietnam. Meteorit Planet Sci 34:757761

Folco L, D'Orazio M, Gemelli M, Rochette P (2016) Stretching out the Australasian microtektite strewn field in Victoria land Transantarctic Mountains. Polar Science 10(2):147-159. https://doi.org/10.1016/j.polar.2016.02.004

Folk RL, Ward W (1957) Brazos river bar; a study in the significance of grain size parameters. J Sediment Petorol 27:3-26

Fudali RF (1993) The stratigraphic age of australites revisited. Meteoritics 28(1): 114-119. https://doi.org/10.1111/j.1945-5100.1993.tb00254.x 
Fudali RF, Dyar MD, Griscom DL, Schreiber HD (1987) The oxidation state of iron in tektite glass. Geochim Cosmochim Acta 51(10):2749-2756. https://doi.org/ 10.1016/0016-7037(87)90154-2

Glass BP, Folco L, Masotta M, Maria VS (2020) Coesite in a Muong nong-type tektite from Muong Phin, Laos: description, formation, and survival. Meteorit Planet Sci 21:1-21. https://doi.org/10.1111/maps.13433

Glass BP, Koeberl C (1989) Trace element study of high- and low-refractive index Muong nong-type tektites from Indochina. Meteoritics 24(3):143-146. https:// doi.org/10.1111/j.1945-5100.1989.tb00956.x

Glass BP, Simonson BM (2012) Distal impact ejecta layers: spherules and more. Elements, 8(1):43-48. https://doi.org/10.2113/gselements.8.1.43

Herzog GF, Alexander CO, Berger EL, Delaney JS, Glass BP (2008) Potassium isotope abundances in Australasian tektites and microtektites. Meteorit Planet Sci 43(10):1641-1657. https://doi.org/10.1111/j.1945-5100.2008. tb00634.x

Jébrak M (1997) Hydrothermal breccias in vein-type ore deposits: a review of mechanisms, morphology and size distribution. Ore Geol Rev 12(3):111-134 https://doi.org/10.1016/S0169-1368(97)00009-7

Keates SG (2000) Tektites and the age paradox in mid-Pleistocene China. Science 289(July):507a.

Koeberl C (1992) Geochemistry and origin of Muong nong-type tektites. Geochim Cosmochim Acta 56:1033-1064

Koeberl C (1994) Tektite origin by hypervelocity asteroidal or cometary impact. In: Dressler BO, Grieve RAF, Sharpton VL (eds) Large meteorite impacts and planetary evolution: Geological Society of America special paper 293. Geological Society of America, Colorado. https://doi.org/10.1130/SPE293p133

Koeberl C, Glass BP (2000) Tektites and the age paradox in mid-Pleistocene China. Science 289(July):507a

La Marche PH, Rauch F, Landford WA (1984) Reaction between water and tektite glass. J Non-Cryst Solids 67(1-3):361-369. https://doi.org/10.1016/00223093(84)90161-3

Langbroek M (2015) Do tektites really date the bifaces from the Bose (Baise) basin. J Hum Evol 80:175-178. https://doi.org/10.1016/j.jhevol.2014.06.019

Michikami T, Hagermann A, Kadokawa T, Yoshida A, Shimada A, Hasegawa S, Tsuchiyama A (2016) Fragment shapes in impact experiments ranging from cratering to catastrophic disruption. Icarus 264:316-330

Nuchanong T, Chaodumrong P, Luengingkasoot M, Burrett C, Techawan S, Silakul T, Stokes RB, Raksaskulwong M, Chotikanatis P, Kraikhong C, Subtavewung P, Assavapatchara S, Imsamut S (eds) (2014) Geology of Thailand. Bureau of Geological Survey, Department of Mineral Resources, Bangkok

Rost R (1969) Sculpturing of moldavites and the problem of micromoldavites. J Geophys Res 74(27):6816-6824

Roy SG, Johnson SE, Koons PO, Jin Z (2012) Fractal analysis and thermal-elastic modeling of a subvolcanic magmatic breccia: the role of post-fragmentation partial melting and thermal fracture in clast size distributions. Geochem Geophys Geosyst 13(5):1-23. https://doi.org/10.1029/2011GC004018

Ruesch O, Sefton-Nash E, Vago JL, Küppers M, Pasckert JH, Khron K, Otto K (2020) In situ fragmentation of lunar blocks and implications for impacts and solarinduced thermal stresses. Icarus 336:113431

Ruiz-Carulla R, Corominas J (2020) Analysis of rockfalls by means of a fractal fragmentation model. Rock Mech Rock Eng 53(3):1433-1455. https://doi.org/ 10.1007/s00603-019-01987-2

Schnetzler CC (1992) Mechanism of Muong nong-type tektite formation and speculation on the source of Australasian tektites. Meteoritics 165: 154-165

Schnetzler CC, McHone JF (1996) Source of Australasian tektites: investigating possible impact sites in Laos. Meteoritics and Planetary Science 31:73-76. http://adsabs.harvard.edu/full/1996 M\&PS...31...73S

Schultz PH, Gault DE (1990) Prolonged global catastrophes from oblique impacts. In: Sharpton VL, Ward PD (eds) Global catastrophes in earth history: Geological Society of America special paper 247. Geological Society of America, Colorado

Songtham W, Duangkrayom J, Jintasakul P (2012) An Australasian tektite from the Yasothon soil series, Noen Sa-nga, Chaiyaphum, northeastern Thailand. Acta Geosci Sin 33(1):59-64. https://doi.org/10.3975/cagsb.2012.s1.28

Songtham W, Mildenhall DC, Jintasakul P, Duangkrayom J (2011) Evidence of sedimentary deposits generated by an Early Pleistocene meteor impact in northeastern Thailand. In: Satarugsa P, Lertsirivorakul R, Kromkhun K, Promkotra S (eds) International conference on geology, Geotechnology and mineral resources of Indochina (GEOINDO 2011), December 2011. Khon Kaen University, Khon Kaen, Department of Geotechnology, pp 66-71

Tada T, Carling PA, Tada R, Songtham W, Thuyen LX, Chang Y, Tajika E (2019) Constraint on the location of the Australasian tektite impact event based on the distribution of the ejecta deposits across the Eastern Indochina. presented at the AGU Fall meeting 2019, San Francisco, 9-13 December 2019.

Takagi Y, Mizutani H, Kawakami SI (1984) Impact fragmentation experiments of basalts and pyrophyllites. Icarus 59(3):462-477. https://doi.org/10.1016/00191035(84)90114-3

Tamura T (1992) Landform development and related environmental changes in the Chi River basin, Northest Thailand. The Science Reports of the Tohoku University, 7th Series (Geography) 42(2):107-127

Turcotte LD (1986) Fractals and fragmentation. J Geophys Res 91(B2):1921-1926. https://doi.org/10.1029/JB091iB02p01921

Wasson JT (1991) Layered tektites: a multiple impact origin for the Australasian tektites. Earth Planet Sci Lett 102(2):95-109. https://doi.org/10.1016/0012$821 X(91) 90001-X$

Wasson JT, Pitakpaivan K, Putthapiban P, Salyapongse S, Thaothimthong B, McHone JF (1995) Field recovery of layered tektites in Northeast Thailand. J Geophys Res 100(E7):14383-14389

Wongsomsak S (1986) Salinization in Northeast Thailand. Southeast Asian Stud 24(2):133-153 http://hdl.handle.net/2433/56243

Xu Y (2018) The fractal evolution of particle fragmentation under different fracture energy. Powder Technol 323:337-345. https://doi.org/10.1016/j. powtec.2017.10.011

\section{Publisher's Note}

Springer Nature remains neutral with regard to jurisdictional claims in published maps and institutional affiliations.

\section{Submit your manuscript to a SpringerOpen ${ }^{\circ}$ journal and benefit from:}

- Convenient online submission

- Rigorous peer review

- Open access: articles freely available online

High visibility within the field

- Retaining the copyright to your article

Submit your next manuscript at $>$ springeropen.com 